\title{
STOP 10: Kame terrace in the Upper Daugava depression at Rakuti, near Krāslava
}

\author{
Vitālijs Zelčs ${ }^{\mathrm{a}}$, Juris Soms ${ }^{\mathrm{b}}$ and Edgars Greiškalns ${ }^{\mathrm{b}}$ \\ ${ }^{\mathrm{a}}$ University of Latvia, Latvia \\ b Daugavpils University, Latvia
}

According to the established deglaciation history of Latvia (Āboltiņš et al. 1972; Meirons et al. 1976; Zelčs and Markots 2004; Zelčs et. al. 2011), the Upper Daugava depression and adjacent glacial uplands were the very first areas to become free of the Fennoscandian ice sheet during the last glacial termination, approximately 16-18 ka BP (Raukas et. al. 1995; Rinterknecht et al. 2006). Consequently, these areas are among those in Latvia which have been exposed to proglacial and non-glacial conditions for the longest period of time. Hence, the geomorphological and geological study of these regions allows reconstruction of the processes and environmental conditions of the events occurring at the end of the Late Pleistocene and beginning of the Early Holocene. In such a context, the possibility of studying the uppermost part of the Late Pleistocene sequence in a number of sections at the Rakuti sand and gravel quarry (Fig. 10.1), with various spatial orientations, permits substantial scientific data to be obtained. The main morphological characteristics and preliminary results of lithological studies from three out of seven studied outcrops (see Fig. 10.1B for location) are demonstrated in this stop description. The quarry covers an area of 4.24 ha and lies 132-134 m a.s.l. During the extraction of sand and gravel the layers of clastic Quaternary sediments are exposed to a depth of up to $12 \mathrm{~m}$.

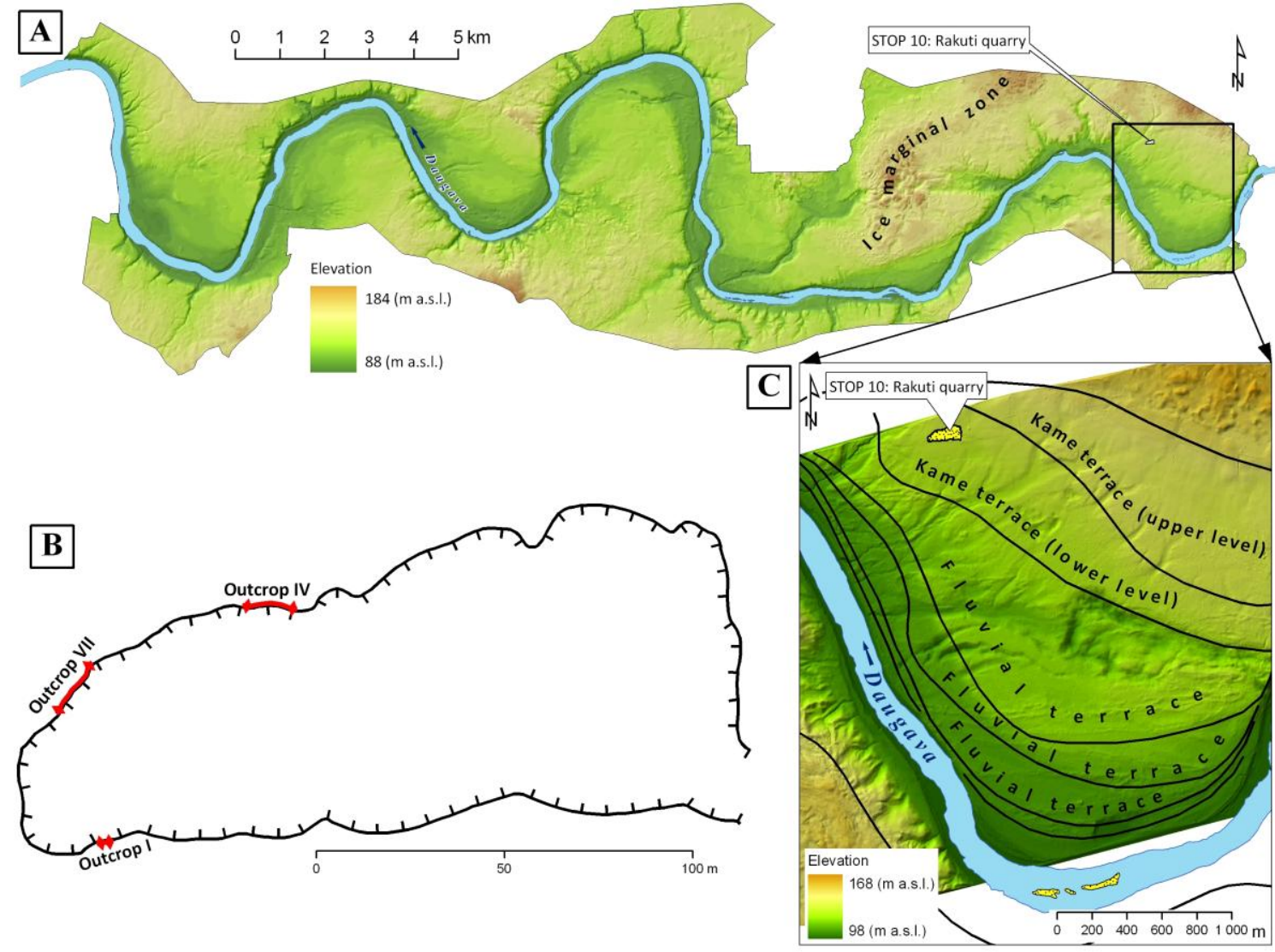

Fig. 10.1. A. Digital elevation model of the Upper Daugava depression and general location of the stop site, distal from the ice-marginal zone. B. Location of the studied outcrops. C. Location of kame and fluvial terraces. 
The Rakuti sand and gravel quarry $\left(55^{\circ} 53^{\prime} 51^{\prime \prime} \mathrm{N}, 27^{\circ} 05^{\prime} 30^{\prime \prime} \mathrm{E}\right)$ is located on a flattopped geomorphic surface complicated by dispersed microforms (e.g. erosional features and small kettle holes) and bounded by the riser of the lowermost terrace, presumed to be fluvial (Fig. 10.1C). Eberhards (1972) has mapped this flat-topped landform, which occurs alongside the northern edge of the Upper Daugava depression, west of the town of Krāslava, as the uppermost terrace or Terrace VIII of the East-Latvian terrace spectrum of the River Daugava. Eberhards (ibid., 2013) and later also Āboltinš (1995) have specified that the terraces (VII to II) were mainly erosional, besides which the terraces of the upper complex (VII-V) were formed by meltwater streams flowing from Lake Polatsk into the Nìcgale ice-dammed lake. However, the course of stream flow during its formation is still an open question, because alongside this terrace the surface slopes slightly to east in the direction of the Polatsk icedammed lake, from 132-134 $\mathrm{m}$ a.s.l. at the quarry down to $128.5 \mathrm{~m}$ a.s.l. for this terrace level, and from $142 \mathrm{~m}$ a.sl. to approximately $138 \mathrm{~m}$ a.s.l. for the uppermost terrace level, over a distance of about $1000 \mathrm{~m}$. Without completely rejecting the idea of meltwater drainage to east, Eberhards (1972) attempted to explain the upstream inclination of the levels of both abovementioned terrace treads, opposite to the modern river flow direction, in terms of glacial isostatic adjustment.

The results of the most recent research lead to a different conclusion and reveal that Terrace VIII is not a fluvial erosional terrace but a kame terrace. The terrace micro-relief and internal structure of the underlying sediments also provide evidence of glaciokarst and periglacial processes, the presence of floating dead ice blocks (Fig. 10.2) and substantial temporal and spatial changes in the depositional environment (Fig. 10.3). These are classic features for identification of kame terraces occurring in various glaciated regions, as noted by Klimek (1956), John (1972), Huddart and Lister (1981), de Jong and Rappol (1983), Bitinas et al. (2004), Pisarska-Jamrozy et al. (2010), and Dauškans (2013).
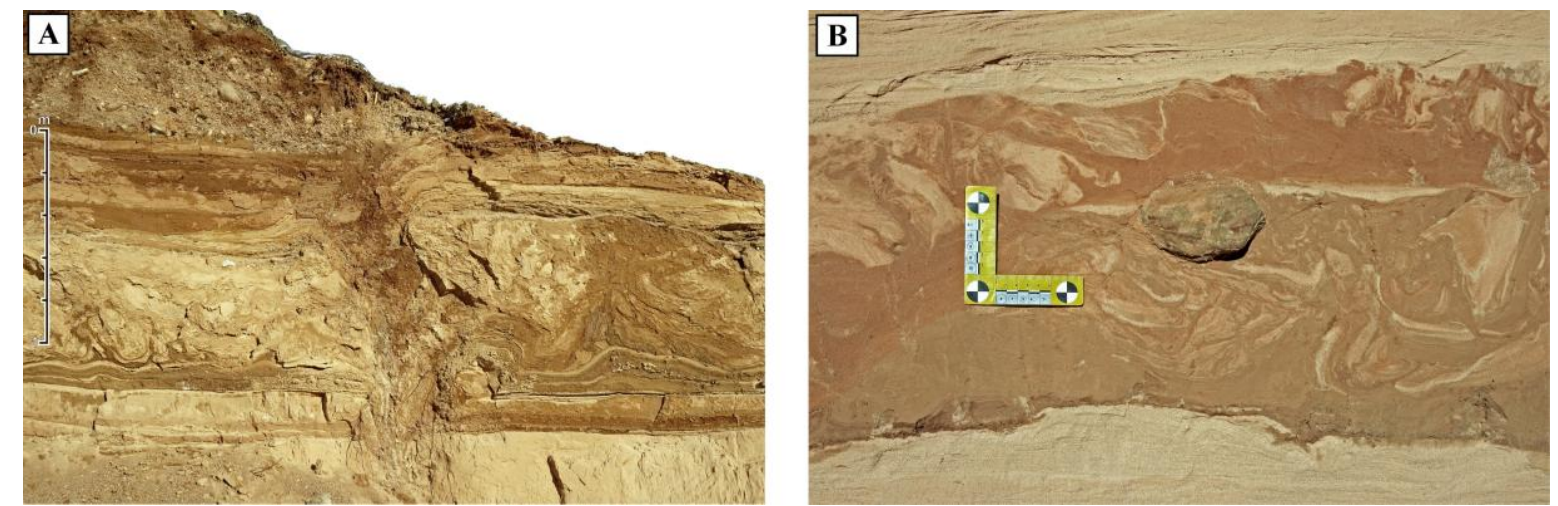

Fig. 10.2. Ice wedge and cryoturbation in horizontally laminated silt and clay interlayered with gravelly sand matrix and occasional cobbles (A) and large dropstone, supposedly, in convoluted and slumped silt and silty sand interlayered with sand (B) in outcrops V and VI located in the NE corner of the Rakuti quarry. Evidently this part was occupied by an ephemeral glaciomarginal lake. The ice wedge and cryoturbation present important evidence of essentially subaerial conditions, which might have been caused by climate deterioration or drainage of this glaciomarginal lake. Besides, occasional carbonate cementation has been observed in the underlying sand. The massively cemented units occur as isolated lenticular patches with a thickness up to $1.5 \mathrm{~m}$.

The kame terrace is located about $20 \mathrm{~km} \mathrm{~W}$ of the highest shoreline (140 m a.s.l.) of the Polatsk ice-dammed lake and $30 \mathrm{~km}$ east of the Nīcgale ice-dammed lake. The Rakuti quarry lies in the proximity of the distal slope of an unnamed ice-marginal zone, considered to be somewhat older than the Kaldabruña ice-marginal position by Meirons et al. (1976), and tentatively assumed to be the Dagda ice marginal zone by Zelčs et al. (2011). According to Zelčs et al. (ibid.), before formation of the Dagda ice marginal features the territory under 
consideration was in the coalescence zone between the Lubāns and Polatsk lobes.

The bedrock surface is on average $85-90 \mathrm{~m}$ a.s.l. In the neighbouring territory on the bottoms of the buried valleys and narrow bedrock depressions it falls to $46 \mathrm{~m}$ b.s.l. The bedrock is Middle Devonian terrigenous sedimentary rock. The thickness of Pleistocene sediments is about 50-60 m, but decreases in the Daugava river valley, reaching $27 \mathrm{~m}$ at Krāslava. The Pleistocene superficial sediments are mapped as Upper Weichselian glaciofluvial gravelly sand (Juškevičs and Skrebels 2003). To the north, in the direction of the Latgale Upland, it is replaced by Late Weichselian till.

Investigation of the internal structure of the sediments underlying the terrace utilised field techniques widely used in Quaternary geology and glacial geomorphology (Hubbard and Glasser 2005), i.e. measurements of long axis orientations of 450 elongate pebbles by identification of their dip and its direction. Simultaneously, 100 pebbles in each of the fractions $8-16 \mathrm{~mm}, 16-32 \mathrm{~mm}$ and $32-64 \mathrm{~mm}$ were collected by dry sieving material from nine layers. Thereafter the three major axes $-\mathrm{a}, \mathrm{b}$ and $\mathrm{c}-$ of each clast were measured by digital callipers and recorded to estimate the shape of pebbles according to the classification of Sneed and Folk (1958). The data were plotted in triangular diagrams using the TriPlot module according to Graham and Midgley (2000).

\section{Outcrop I}

Matrix supported massive diamicton interlayered by boulder diamicton and gravelly sand is underlain by silty sand. In the basal part the silty sand becomes coarser and contains gravel. The lower bed consists of planar cross-stratified fine to medium-grained sand, the structure of which is excellently visible in the sections striking perpendicular to this outcrop.

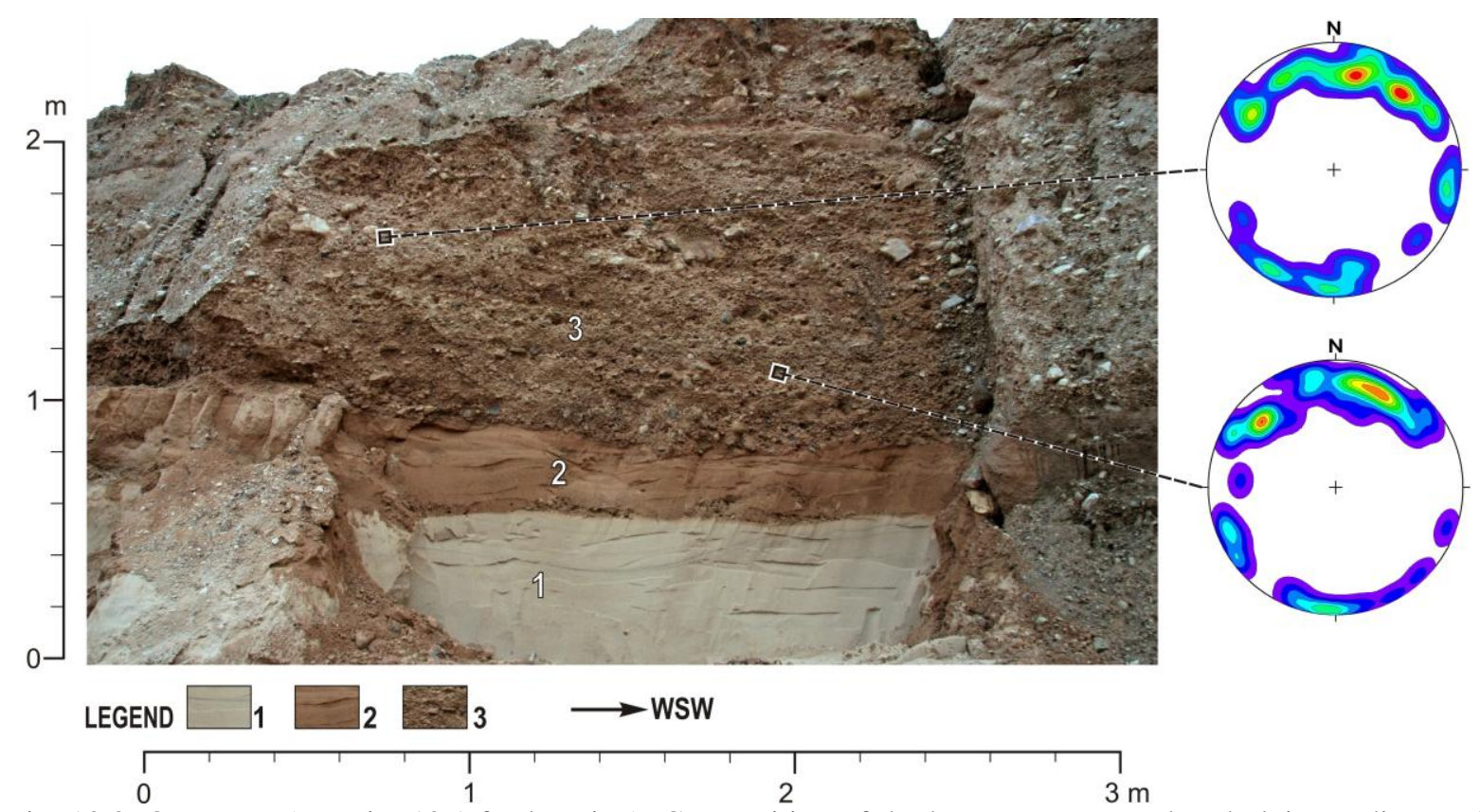

Fig. 10.3. Outcrop I (see Fig. 10.1 for location). Composition of the kame terrace tread underlying sediments is shown in the section subparallel to the terrace stretch. Legend of identified layers: 1 - planar cross-stratified fine to medium-grained sand; 2 - trough cross-stratified silty sand with occasional gravel and gravel lenses in the basal part; 3 - massive, matrix supported clast rich diamicton, interlayered with gravelly sand.

Three-dimensional diagrams of clast orientation are on the lower hemisphere and in equal area projection. Based on 50 elongated clast measurements. Contoured at $0-1-2 \ldots 6-8$ percent areas.

The measurements of the orientation of clasts indicate a relatively weak to moderately strong multimodal azimuth. The dip varies across a wide range. However, it indicates the 
gravity flow direction from the melting stagnant ice lobe to the lateral slope. The diamicton is interpreted as flow till re-deposited by dense cohesive flow, whereas the underlying silty sand with an admixture coarse grained particles has perhaps been deposited as fluidised sediment flow, but its structure has been slightly altered by deformation. The lower sedimentary unit represents a delta foreset series.

\section{Outcrop IV}

The uppermost part of the exposed section is similar to Outcrop I. For instance, unit 7 can be conditionally correlated with unit 1 of outcrop I (Figs. 10.3 and 10.4). Five beds of diamicton lithofacies can be distinguished in the section. Excluding units 7 and 8, the lower boundaries of other diamicton units with horizontally laminated sand and fines are sharp, presumably erosional, but the boundary between units 5 and 4 is also marked by erosional scours (Fig. 10.4). The results of orientation of the elongated clasts mainly show multimodal azimuth patterns. Only in unit 3 and unit 5 clast linearity is quite strong and indicates flow direction at an oblique angle to the stagnant ice.

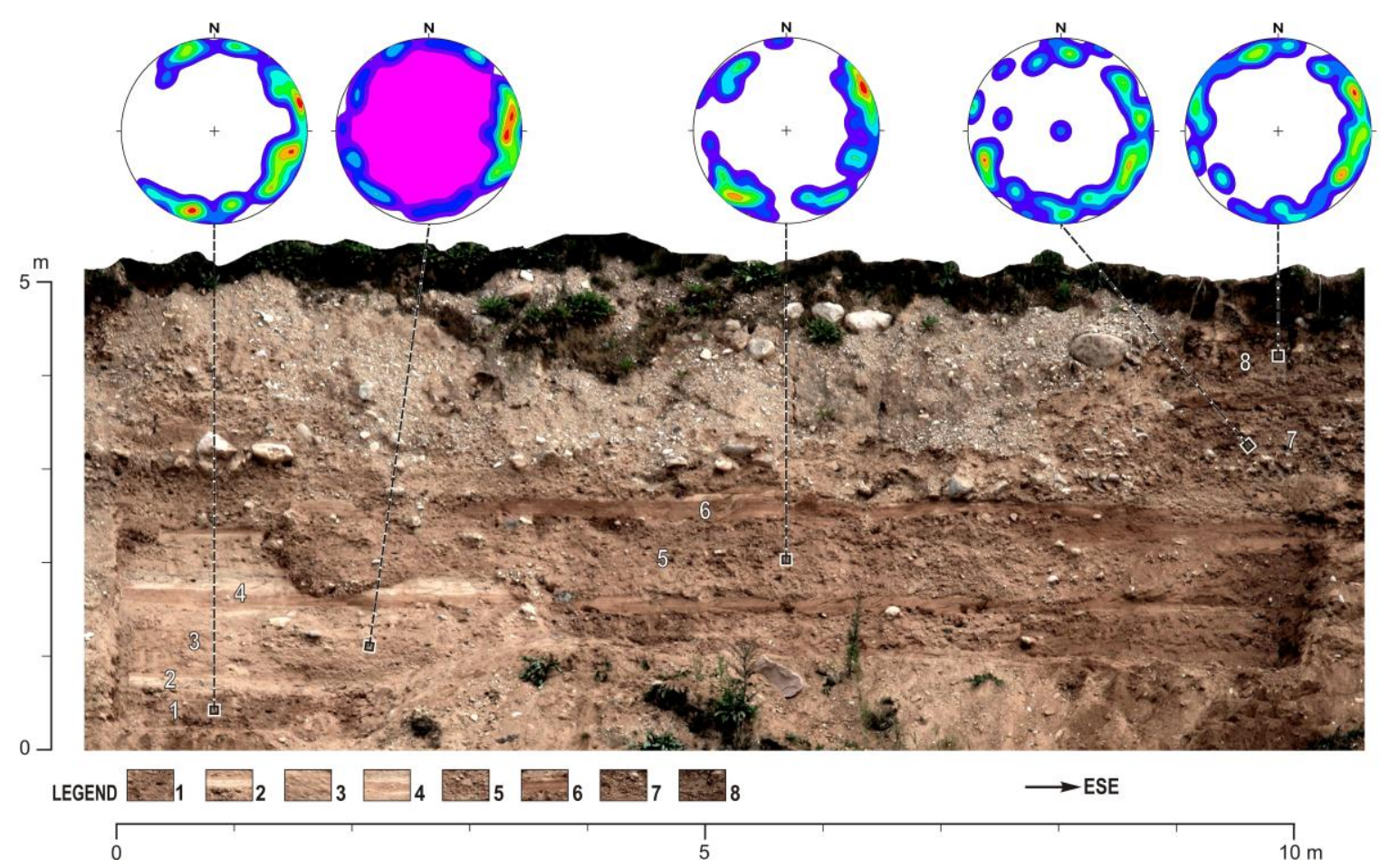

Fig. 10.4. Outcrop IV (see Fig. 10.1 for location). Composition of the sediments underlying the kame terrace tread is shown in the section alongside the terrace stretch. Legend of identified layers: 1 - matrix supported, clast moderate, massive diamicton; 2 - horizontally laminated silty sand; 3 - massive, matrix supported, clast moderate diamicton; 4 - fine sand and sandy silt, horizontally laminated; 5 - massive, matrix supported, clast moderate diamicton; 6 - horizontally laminated fines; 7 - matrix supported, clast rich diamicton with boulder concentration zone; 8 - clast supported diamicton with boulder concentration on the top.

The three-dimensional diagrams of clast orientation are on the lower hemisphere and in equal area projection. Based on 50 elongated clast measurements. Contoured at 0-1-2...6-8 percent areas.

\section{Outcrop VII}

This outcrop is situated at the NW corner of the quarry (Fig. 10.1). It displays an alternation of sedimentary units consisting of coarse clastic and finer material (Fig. 10.5). Some of them can be correlated with units occurring in Outcrop IV. The orientation maxima of the elongated clasts are well-expressed. They indicate a debris flow direction parallel or 
subparallel to the kame terrace stretch.

Analysis of field study data demonstrate that in the western part of the quarry clastic sediments are dominant and mainly consist of poorly sorted gravel with pebbles, and bouldersize material in places, with a sandy loam matrix (Figs. 10.3, 10.4 and 10.5). The coarse clastic material is interlayered with basin sediments, and underlain by planar cross-stratified fine to medium-grained sand in the western part of the quarry. Eastwards this well-sorted sand is replaced by rippled and horizontally laminated sandy silt, evidently deposited in a shallow lake. The role of basin deposition in the topmost part of the sediment sequence also increases in the same direction.

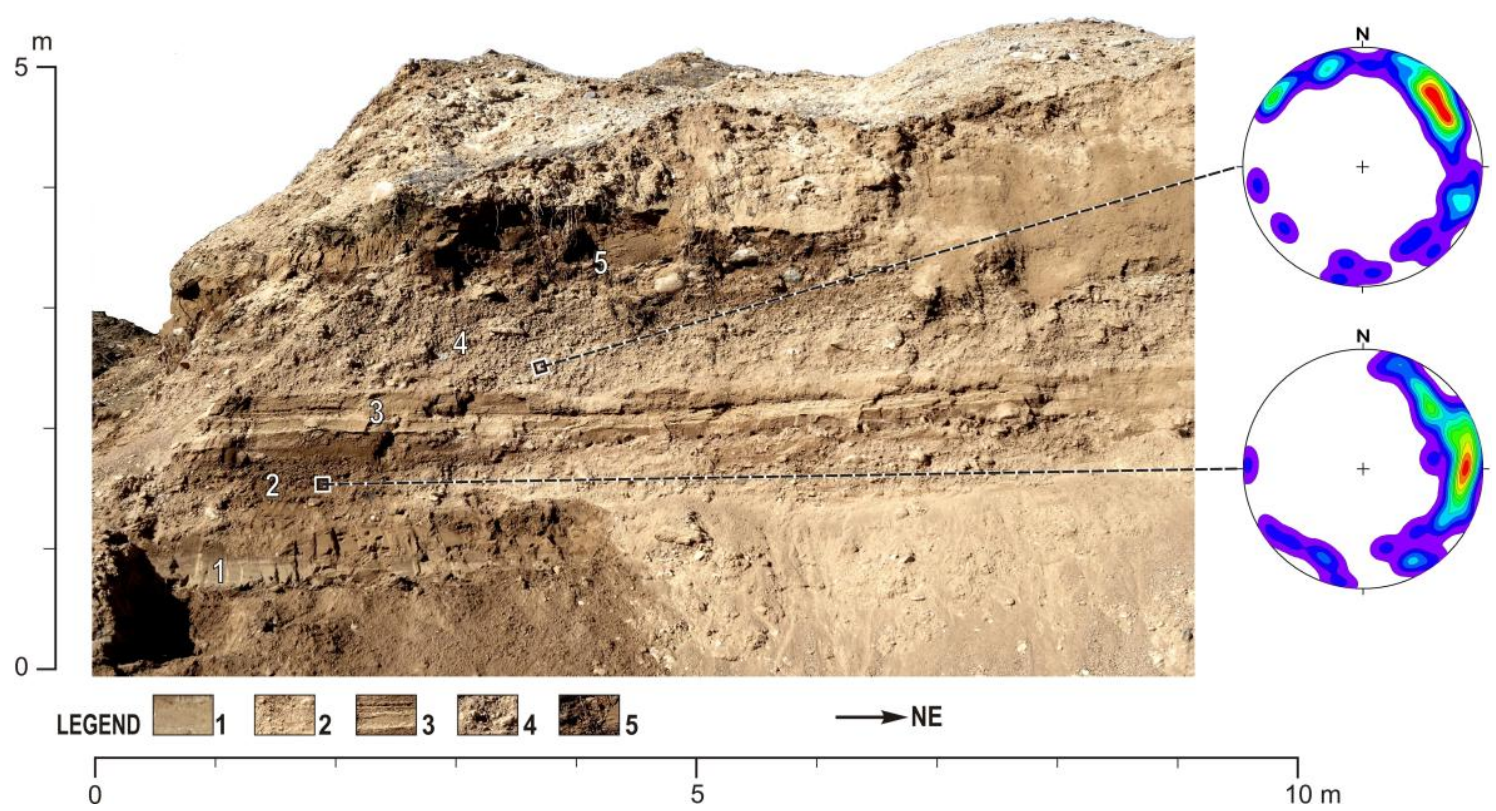

Fig. 10.5. Outcrop IV (see Fig. 10.1 for location). Composition of the sediments underlying the kame terrace tread is shown in the section transverse to the terrace stretch. Legend of identified layers: 1 - horizontally laminated sandy silt (in Fig. 10.4: unit 4); 2 - massive, matrix supported, clast moderate to rich, gravelly diamicton; 3 - horizontally laminated silt and rippled fine sand interlayers; 4 - clast supported diamicton with occasional cobbles and boulder concentration zone (tentatively correlated to unit 7 in Fig. 10.4); 5 - deformed diamicton with admixture of fines and occasional boulders.

Three-dimensional diagrams of clast orientation are on the lower hemisphere and in equal area projection. Based on 50 macrofabric measurements. Contoured at 0-1-2...6-8 percent areas.

Pebble- to boulder-sized clasts are mostly unconsolidated and their roundness varies widely from well-rounded to sub-angular. Clasts of the limestone and dolomite lithological groups dominate in all examined layers of diamicton, the proportion of clasts of carbonate rocks varying from $70 \%$ to $82 \%$ of the total number of pebbles. Estimation of the shape of pebbles according to the Sneed and Folk (1958) classification indicates that compact-bladed and bladed clasts are dominant; however, such a shape is not typical for glacial sediments. In addition, the analysis of data on the ratio of the shortest to longest axis of pebbles, i.e. c/a-axis $\leq 0.4$ (termed the $\mathrm{C}_{40}$ index) according to Graham and Midgley (2000), demonstrates that all values plotted in triangular diagrams are located both above and below the $\mathrm{C}_{40}$ index line, although the values of pebbles of crystalline lithology are located mainly above it. Such a distribution of values in triangular diagrams is not typical for subglacially transported sediments, which are usually characterized by a concentration of points above the $\mathrm{C}_{40}$ line (Graham and Midgley 2000). A feasible explanation of this finding is that pebbles of carbonate lithology reflect a short transport distance of deposited clastic sediments.

In most cases the clast linearity coincides with the stretch of the kame terrace, indicating 
that debris was transported from the ice marginal zone. However, in some cases clasts have been oriented at an oblique angle to the stagnant ice or the lateral slope of the Upper Daugava depression. Such a clast spatial orientation and erosional marks on the lateral slope as well as on the scarp of the upper kame terrace level (Fig. 10.1) suggest that proglacial waters have been produced not only by ice melting but also by extra-glacial waters draining from the already ice-free parts of the Latgale Upland.

It is likely that the kame terraces at Rakuti are located where meltwater flowed between stagnant ice and the lateral slope of the Upper Daugava depression. Deposition from stagnant ice and extraglacial waters, and in an ephemeral glaciomarginal lake has resulted in continuous kame terrace.

\section{References}

Āboltinšs, O. P., Veinbergs, I. G., Stelle, V. J., Eberhards, G. J. 1972. Osnovniye kompleksy marginal'nykh obrazovaniy i otstupaniye lednika na territorii Latviiskoy SSR [Main complexes of marginal formations and glacier retreat in the territory of Latvian SSR]. In: Goretskij, G. I., Pogulajev, D. I., Shick, S. M. (eds.), Krayevye obrazovaniya materikovykh oledeneniy [Marginal formations of continental glaciations]. Nauka, Moskva, pp. 30-37 (in Russian).

Bitinas, A., Karmaziene, D., Jusiene, A. 2004. Glaciolacustrine kame terraces as an indicator of conditions of deglaciation in Lithuania during the Last Glaciation. Sedimentary Geology, 165(3-4), 285-294.

Dauškans, M. 2013. Kēmu terases Austrumlatvijas augstienēs. LU Akadēmiskais apgāds, Rīga, 126 lpp.

Eberhards, G. 1972. Stroyeniye i razvitiye dolin basseyna peki Daugava [Structure and development of valleys of the Daugava river basin]. Zinātne, Rīga, 131 pp. (In Russian)

Eberhards, G. 2013. Upju ieleju veidošanās un mūsdienu gultnes procesi dienvidaustrumu Baltijā. Latvijas Universitāte, Rīga, 211 lpp.

Graham, D.J., Midgley, N.G. 2000. Graphical representation of particle shape using triangular diagrams: an Excel spreadsheet method. Earth Surface Processes and Landforms, 25 (13), 1473-1477.

Hubbard, B., Glasser, N. 2005 Field Techniques in Glaciology and Glacial Geomorphology. John Wiley \& Sons, Chichester, 412 pp.

Huddart, D., Lister, H. 1981. The Origin of Ice Marginal Terraces and Contact Ridges of East Kangerdluarssuk Glacier, SW Greenland. Geografiska Annaler, 63A, 31-39.

John, B.S. 1972. A Late Weichselian Kame Terrace at Mullock Bridge, Pembrokeshire. Proceedings of the Geologists Association, Elsevier Ltd., London, pp. 213-229.

de Jong, M.G.G., Rappol M. 1983. Ice-marginal debris flow deposits in western Allgau,southern east Germany. Boreas, 12, 57-70.

Juškevičs, V., Skrebels, J. 2003. Quaternary deposits. In: Āboltiňš, O., Brangulis, A.J. (eds.), Geological Map of Latvia. Scale 1:200,000. Sheet 34-Jēkabpils. Sheet 24-Daugavpils. Explanatory Text and Maps. State Geological Survey, Rīga, pp. 10-29.

Meirons, Z., Straume, J., Juškevičs, V. 1976. Main varieties of the marginal formations and deglaciation of the Last glaciation in the territory of the Latvian SSR. In Danilāns, I. (ed.), Problems of Quaternary Geology, 9. Rìga, Zinātne, pp. 50-73 (in Russian, with English summary).

Pisarska-Jamrozy, M., Machowiak, K., Krzyszkowski, D. 2010. Sedimentation style of a Pleistocene kame terrace from the Western Sudety Mountains, S Poland. Geologos, 16 (2), 101-110.

Raukas, A., Āboltiņ̌̌, O., Gaigalas, A. 1995. The Baltic states. Overview. In: Shirmer, W. (ed.), Quaternary field trips in Central Europe, 1. München, Verlag Dr. Friedrich Pfeil, pp.146-151.

Rinterknecht V. R., Clark P. U., Raisbeck G. M., Yiou F., Bitinas A., Brook E. J., Marks L., Zelčs V., Lunkka J.P., Pavlovskaya I. E., Piotrowski J. A., Raukas A. 2006. The Last Deglaciation of the Southeastern Sector of the Scandinavian Ice Sheet. Science, 311, 10 March 2006, 1449-1452.

Sneed, E.D., Folk, R.L. 1958. Pebbles in the lower Colorado River, Texas, a study of particle morphogenesis. Journal of Geology, 66 (2), 114-150.

Zelčs, V., Markots, A. 2004. Deglaciation history of Latvia. In: Ehlers, J., Gibbard, P. L. (eds.), Quaternary Glaciations - Extent and Chronology. Part I: Europe. Developments in Quaternary Science, 2. Elsevier, Amsterdam, pp. 225-243.

Zelčs, V., Markots, A., Nartišs, M., Saks, T. 2011. Chapter 18: Pleistocene Glaciations in Latvia. In: Ehlers, J., Gibbard, P.L., Hughes, P.D. (eds.), Quaternary glaciations - extent and chronology. A closer look. Developments in Quaternary Science, 15. Elsevier, pp. 221-229. 

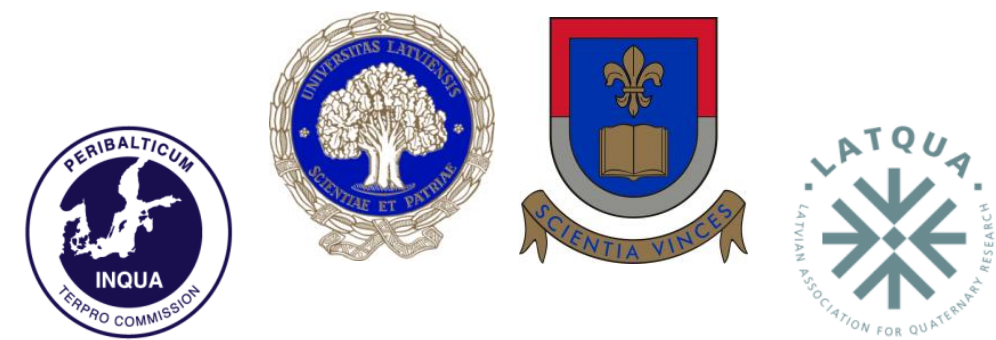

INQUA TERPRO COMMISSION PERIBALTIC WORKING GROUP

UNIVERSITY OF LATVIA

UNIVERSITY OF DAUGAVPILS

LATVIAN ASSOCIATION FOR QUATERNARY RESEARCH

\section{LATE QUATERNARY \\ TERRESTRIAL PROCESSES, SEDIMENTS AND HISTORY: FROM GLACIAL TO POSTGLACIAL ENVIRONMENTS}

EASTERN AND CENTRAL LATVIA

AUGUST 17-22, 2014 


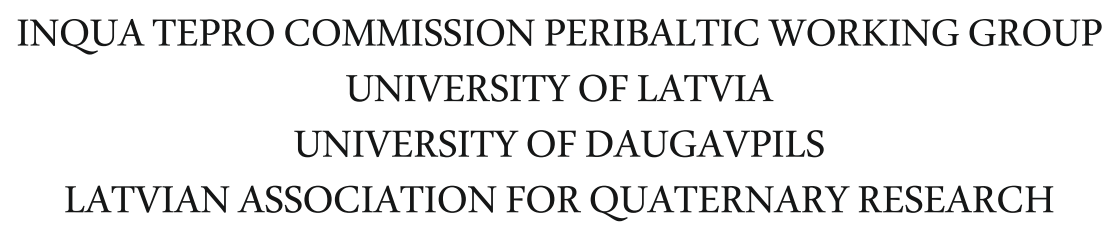

\title{
LATE QUATERNARY \\ TERRESTRIAL PROCESSES, SEDIMENTS AND HISTORY: FROM GLACIAL TO POSTGLACIAL ENVIRONMENTS
}

\author{
EASTERN AND CENTRAL LATVIA
}

AUGUST 16-22, 2014 
Organized by:

University of Latvia

Daugavpils University

Latvian Association for Quaternary Research

INQUA Peribaltic Working Group (INQUA TERPRO Commission)

Organizing committee:

Māris Nartišs (Chair, University of Latvia)

Māris Krievāns (Secretary, University of Latvia)

Aivars Markots (University of Latvia)

Juris Soms (Daugavpils University)

Evija Tērauda (University of Latvia)

Vitālijs Zelčs (University of Latvia)

Contributors:

Ivars Celiņš, Edgars Greiškalns, Ieva Grudzinska, Edyta Kalińska-Nartiša, Laimdota Kalniņa, Jānis Karušs, Māris Krievāns, Kristaps Lamsters, Aivars Markots, Māris Nartišs, Agnis Rečs, Normunds Stivriņš, Juris Soms, Ivars Strautnieks, Santa Strode, Sandra Zeimule, Vitālijs Zelčs

Editors: Vitālijs Zelčs and Māris Nartišs

The English texts of the field guide were revised by Valdis Bērziņš

Recommended reference for this publication:

Zelčs, V. and Nartišs, M. (eds.) 2014. Late Quaternary terrestrial processes, sediments and history: from glacial to postglacial environments. Excursion guide and abstracts of the INQUA Peribaltic Working Group Meeting and field excursion in Eastern and Central Latvia, August 17-22, 2014. University of Latvia, Rīga, 2014, 150 pages.

Sponsored by:

University of Latvia

Layout: Vitālijs Zelčs, Māris Nartišs and Māris Krievāns

ISBN 078-9934-517-60-0

(C) University of Latvia, 2014

This volume is available from:

Faculty of Geography and Earth Sciences

University of Latvia

Rainis Blvd. 19

Rìga, LV1586

Latvia 